\title{
The effect of single and double curvature in optimum design of slender reinforced concrete columns
}

\author{
Gebrail Bekdaş
}

\author{
Sinan Melih Niğdeli
}

\author{
Baris Sayin
}

\begin{abstract}
Slenderness is an important factor in the design of long reinforced concrete ( $\mathrm{RC})$ columns. It is also a major problem for RC columns which are restricted to lateral displacement. In that case, buckling is effective on the second the second order effects. The elastic curve of the columns may have single or double curvature. The type of curvature is effective on slenderness of the column. In ACI318-Building code requirements for structural concrete-, an effect of slenderness is considered by using a moment magnification factor. In this factor, the type of curvature is also considered by a correction factor $\left(C_{m}\right)$ which is defined according to end moments. For that reason, different flexural moment cases are presented in the present study. By employing teaching learning based optimization, the cost optimization of the columns was done. According to the results, the type of curvature is effective on the optimum design and cost.
\end{abstract}

Keywords - Reinforced concrete, slenderness, columns, optimization, metaheuristic methods, teaching learning based optimization

\section{Introduction}

The optimum design of reinforced concrete (RC) member is an important area for engineers because the economy and safety are the main aims of engineers. Optimization is challenging problem for reinforced concrete members considering of concrete and steel. These two materials have different strength behaviors and costs.

The optimization of RC columns has been investigated in several studies [1-6]. Also, metaheuristic algorithms are very effective on optimum design of RC member. The nature inspired Genetic algorithm (GA) [7-8] was employed in the optimum design of RC columns [9], RC frames [10-13], RC continuous beams [14], RC T-shaped beams [15] and various RC members [16]. GA is also combined with methods such as sequential quadratic programing [17], Hook and Jeeves method [18] and Simulated Annealing (SA) [19] in the optimum design of RC members.

Gebrail Bekdaş

Department of Civil Engineering / Istanbul University

Turkey

Sinan Melih Niğdeli

Department of Civil Engineering / Istanbul University Turkey

Baris Sayin

Department of Civil Engineering / Istanbul University Turkey
SA is also a metaheuristic algorithm inspired by the annealing process of a material [20] and it is employed in the optimum design of RC frames [21] and RC bridges [22]. Most of the optimization studies about RC design consider the minimization of the total cost. In addition to that, the minimum embedded $\mathrm{CO}_{2}$ emission was also considered in the methodologies employing SA [23] and big bang-big crunch (BB-BC) algorithm [24]. BB-BC inspired from the evolution of the universe [25] was also employed by Kaveh and Sabzi for RC frames [26]. Additionally, the RC retaining wall is an important member in structural engineering. In order to consider the geotechnical and structural constraint in design of RC retaining walls, SA [27-28], BB-BC [29], harmony search (HS) [30], charged system search (CSS) [31] and teaching learning based optimization [32] were employed. The music inspired HS [33] was employed in the optimum design of RC continuous beams [34], RC frames [35], T-shaped RC beams [36-37], RC slender columns [38]. TLBO is an education inspired method [39] and it was also employed in the optimum design of slender RC columns [40].

In this study, the optimum design of RC slender columns was investigated for different end moment cases. In that case, it is possible to consider the type of the curvature in the optimum design. In the optimization, TLBO based method [40] was used by considering ACI 318-Building code requirements for structural concrete [41].

\section{Methodology}

The effect of slenderness can be taken into consideration by using the approximate procedure defined in ACI 318 [41]. According to the procedure, the maximum flexural moment of the column is multiplied by the moment magnification factor $(\delta s)$. This factor is calculated according to the buckling behavior of the column. The effective length in buckling $(\mathrm{k})$ is calculated by considering $\Psi \mathrm{A}$ and $\Psi \mathrm{B}$ (Eq. 1) for upper and lower ends of the columns, respectively.

$$
\Psi_{A, B}=\frac{\sum(E I / l)_{\text {column }}}{\sum(E I / l)_{\text {beam }}}
$$

$$
\Psi_{m}=0.5\left(\Psi_{A}+\Psi_{B}\right)
$$

$$
k=\frac{20-\Psi_{m}}{20} \sqrt{1+\Psi_{m}} \quad \text { if } \Psi_{m}<2
$$


Proc. of the Fourth International Conference on Advances in Civil, Structural and Environmental Engineering - ACSEE 2016. Copyright $\odot$ Institute of Research Engineers and Doctors. All rights reserved.

ISBN: 978-1-63248-114-6 doi: 10.15224/ 978-1-63248-114-6-24

$$
k=0.9 \sqrt{1+\Psi_{m}} \quad \text { if } \Psi_{m} \geq 2
$$

In Eq. (1), E, I, and 1 are elasticity modulus, moment of inertia and length of the RC members, respectively. The rigidity (EI) of columns and beams are multiplied by 0.65 and 0.3 in order to consider the cracking of the concrete sections. Then $\mathrm{k}$ is calculated according to end conditions of the column. For example, $\mathrm{k}$ is obtained according to following equations if the column is free to make lateral displacement

The moment magnification factor $(\delta \mathrm{s})$ is found according to Eq. (5) in which the design axial force, the buckling force and correction factor considering actual moment diagram to end equivalent moment diagram are shown with $\mathrm{Pu}, \mathrm{Pc}$ and $\mathrm{Cm}$, respectively.

$$
\delta_{s}=\frac{C_{m}}{1-\frac{P_{u}}{0.75 P_{c}}}
$$

The correction factor defined in Eq. (6) is calculated according to end moment defined as M1 and M2. M2 is the biggest one in absolute value $\mathrm{In}$ that case, $\mathrm{Cm}$ is taken between 0.4 and 1.0 .

$$
C_{m}=0.6+0.4 \frac{M_{1}}{M_{2}}
$$

The buckling load can be calculated by the equation of Euler as seen in Eq. (7).

$$
P_{c}=\frac{\pi^{2} E I}{(k l)^{2}}
$$

During the optimization, the maximum design flexural moment is factored with $\delta \mathrm{c}$. The column is subjected to flexural moment, shear force (V) and axial force (Pu). These forces are defined with the other design constant such as clear cover of concrete; cc, maximum aggregate diameter; Dmax, length of column; 1, elasticity modulus of steel; Es, cost of the concrete per m3; Cc, cost of the steel per ton; Cs, compressive strength of concrete; yield strength of steel; fy, specific gravity of steel; $\gamma \mathrm{s}$ and specific gravity of concrete; $\gamma \mathrm{c}$. The ranges of design variables are also defined and the design variables are breadth, height and reinforcements (number, diameter and space) of column. The optimization is an iterative process and TLBO algorithm is employed as done by Bekdas and Nigdeli [40]. The two phases such as teacher and learner phases are consequently used in generation of new possible solutions. For all generations, the analyses are done considering ACI318 constraints and the total material cost is calculated. The aim of the optimization is to minimize the total cost.

\section{Numerical Example}

The investigation is done for seven cases of the external forces as seen in Table 1. In these cases, the minimum flexural moment is different. According to the different values, $\mathrm{Cm}$, values and shear forces $(\mathrm{V})$ change. In the first two cases, the elastic curve of the column has double curvature. In the other cases, the single curvature is observed and the second order effects are increasing. The design constants; length of column (l), clear cover (cc), maximum aggregate diameters (Dmax), yield strength of steel (fy), compressive strength of concrete (fc), elasticity modulus of steel (Es), specific gravity of steel $(\gamma \mathrm{s})$, cost of concrete per $\mathrm{m} 3$ and cost of steel per ton were taken as $10.0 \mathrm{~m}, 30 \mathrm{~mm}, 16 \mathrm{~mm}, 420 \mathrm{MPa}, 25 \mathrm{MPa}, 200000$ $\mathrm{MPa}, 7.86 \mathrm{t} / \mathrm{m} 3,40 \$$ and $400 \$$, respectively. The design variable ranges of breadth (bw), height (h), longitudinal reinforcement diameter and shear reinforcement diameter were taken as $250 \mathrm{~mm}-400 \mathrm{~mm}, 300 \mathrm{~mm}-600 \mathrm{~mm}, 16 \mathrm{~mm}-30 \mathrm{~mm}$ and $8 \mathrm{~mm}-14 \mathrm{~mm}$, respectively. The dimension values were assigned with the multiples of $10 \mathrm{~mm}$ for practical design. Also, the sizes of reinforcement were assigned with even values. The optimum results are presented in Table 2 .

\begin{tabular}{|c|c|c|c|c|c|c|c|}
\hline Cases & 1 & 2 & 3 & 4 & 5 & 6 & 7 \\
\hline Breadth of column $\left(b_{w}\right)(\mathrm{mm})$ & 470 & 500 & 530 & 570 & 600 & 600 & 600 \\
\hline Height of column (h) (mm) & 600 & 600 & 600 & 600 & 600 & 600 & 600 \\
\hline Bars in each face & $2 \Phi 24$ & $\begin{array}{l}1 \Phi 26+1 \Phi 20+ \\
1 \Phi 18\end{array}$ & $\begin{array}{l}1 \Phi 16+1 \Phi 2 \\
0+1 \Phi 22\end{array}$ & $\begin{array}{l}1 \Phi 18+1 \\
\Phi 20+1 \Phi \\
22\end{array}$ & $\begin{array}{l}1 \Phi 20+1 \\
\Phi 18+1 \Phi \\
16\end{array}$ & $\begin{array}{l}2 \Phi 20+ \\
1 \Phi 28+1 \Phi 1 \\
8+2 \Phi 16\end{array}$ & $\begin{array}{l}4 \Phi 20+ \\
3 \Phi 18+2 \\
\Phi 16\end{array}$ \\
\hline Web reinforcements & $2 \Phi 18$ & $2 \Phi 16$ & $2 \Phi 16$ & $2 \Phi 18$ & $2 \Phi 16$ & $2 \Phi 16$ & $2 \Phi 16$ \\
\hline Shear reinforcement diameter $(\mathrm{mm})$ & $\Phi 8$ & Ф8 & Ф8 & Ф8 & $\Phi 8$ & Ф8 & $\Phi 8$ \\
\hline Shear reinforcement distance $(\mathrm{mm})$ & 250 & 240 & 220 & 210 & 200 & 200 & 200 \\
\hline Optimum cost $(\$)$ & 214.09 & 224.48 & 242.25 & 258.62 & 272.06 & 303.26 & 335.64 \\
\hline
\end{tabular}

TABLE I. THE DESIGN CASES OF OPTIMIZAITON PROCESS

\begin{tabular}{llllllll}
\hline Cases & $\mathbf{1}$ & $\mathbf{2}$ & $\mathbf{3}$ & $\mathbf{4}$ & $\mathbf{5}$ & $\mathbf{6}$ & $\mathbf{7}$ \\
\hline $\mathrm{M}_{1}(\mathrm{kNm})$ & -250 & -125 & 0 & 125 & 250 & 375 & 500 \\
$\mathrm{M}_{2}(\mathrm{kNm})$ & 500 & 500 & 500 & 500 & 500 & 500 & 500 \\
$\mathrm{P}_{\mathrm{u}}(\mathrm{kN})$ & 3500 & 3500 & 3500 & 3500 & 3500 & 3500 & 3500 \\
$\mathrm{~V}(\mathrm{kN})$ & 75.0 & 62.5 & 50.0 & 37.5 & 25.0 & 12.5 & 0 \\
$\mathrm{C}_{\mathrm{m}}$ & 0.4 & 0.5 & 0.6 & 0.7 & 0.8 & 0.9 & 1.0 \\
\hline
\end{tabular}

TABLE II. THE OPTIMIUM RESULTS AND COSTS 
Proc. of the Fourth International Conference on Advances in Civil, Structural and Environmental Engineering - ACSEE 2016. Copyright $\odot$ Institute of Research Engineers and Doctors. All rights reserved.

ISBN: 978-1-63248-114-6 doi: 10.15224/ 978-1-63248-114-6-24

\section{Conclusions}

According to the optimum results of numerical example, the optimum cost has an increasing manner by the increase of the minimum end moment. In that case, the effect of the type of the curvature and the slenderness can be seen. This situation shows the importance of the slenderness although the value of the shear force is decreasing by the reduction of the difference of the end moments.

The aim of the optimization process is to reduce the slenderness because the height of the column is at the upper bound of the solution range for all cases. By the increase of the slenderness, the breadth of the columns are also increasing and it is also at the upper bound for the last three cases.

The employed metaheuristic algorithms called TLBO is also effective to find the optimum design supporting the effect of the slenderness.

\section{References}

[1] C.C Ferreira, M.H.F.M. Barros, A.F.M. Barros, "Optimal design of reinforced concrete T-sections in bending", Eng. Struct., 25, 951-964, 2003.

[2] J.R. Balling, X. Yao, "Optimization of Reinforced Concrete Frames", J Struct. Eng.-ASCE, 123, 193-202, 1997.

[3] M.H.F.M. Barros, R.A.F. Martins, A.F.M. Barros, "Cost optimization of singly and doubly reinforced concrete beams with EC2-2001", Struct. Multidiscip. O., 30, 236-242, 2005.

[4] A. Guerra, P.D. Kiousis, "Design optimization of reinforced concrete structures", Comput. Concrete., 3, 313-334, 2006.

[5] L.M. Gil-Martin, E. Hernandez-Montes, M. Aschheim, "Optimal reinforcement of RC columns for biaxial bending", Mater. Struct., 43, 1245-1256, 2010

[6] A.F.M. Barros, M.H.F.M. Barros, C.C. Ferreira, "Optimal design of rectangular RC sections for ultimate bending strength", Struct. Multidiscip. O., 45, 845-860, 2012.

[7] J.H. Holland, "Adaptation in Natural and Artificial Systems", University of Michigan Press, Ann Arbor, Michigan, 1975.

[8] D.E. Goldberg, "Genetic algorithms in search, Optimization and machine learning", Addison Wesley, Boston, Massachusetts, 1989.

[9] M.Y. Rafiq, C. Southcombe, "Genetic algorithms in optimal design and detailing of reinforced concrete biaxial columns supported by a declarative approach for capacity checking", Comput. Struct., 69, 443457, 1998.

[10] S. Rajeev, C.S. Krishnamoorthy, "Genetic Algorithm-Based Methodology for Design Optimization of Reinforced Concrete Frames", Comput-Aided Civ. Inf., 13, 63-74, 1998.

[11] C. Lee, J. Ahn, "Flexural Design of Reinforced Concrete Frames by Genetic Algorithm", J Struct. Eng.-ASCE, 129(6), 762-774, 2003.

[12] C.V. Camp, S. Pezeshk, H. Hansson, "Flexural Design of Reinforced Concrete Frames Using a Genetic Algorithm", J Struct. Eng.-ASCE, 129, 105-11, 2003.

[13] V. Govindaraj, J.V. Ramasamy, "Optimum detailed design of reinforced concrete frames using genetic algorithms", Eng. Optimiz., 39(4), 471494, 2007.

[14] V. Govindaraj, J.V. Ramasamy, "Optimum detailed design of reinforced concrete continuous beams using Genetic Algorithms", Comput. Struct., 84, 34-48, 2005.
[15] F. Fedghouche, B. Tiliouine, "Minimum cost design of reinforced concrete T-beams at ultimate loads using Eurocode2." Eng. Struct., 42, $43-50,2012$.

[16] V.K. Koumousis, S.J. Arsenis, "Genetic Algorithms in Optimal Detailed Design of Reinforced Concrete Members", Comput-Aided Civ. Inf., 13, 43-52, 1998

[17] D.P. Rath, A.S. Ahlawat, A. Ramaswamy, "Shape Optimization of RC Flexural Members", J Struct. Eng.-ASCE, 125, 1439-1446, 1999.

[18] M.G. Sahab, A.F. Ashour, V.V. Toropov, "Cost optimisation of reinforced concrete flat slab buildings", Eng. Struct., 27, 313-322, 2005.

[19] M. Leps, M. Sejnoha, "New approach to optimization of reinforced concrete beams", Comput. Struct., 81, 1957-1966, 2003.

[20] S. Kirkpatrick, C. Gelatt, M. Vecchi, "Optimization by simulated annealing", Science, 220, 671-680, 1983.

[21] I. Paya, V. Yepes, F. Gonzalez-Vidosa, A. Hospitaler, "Multiobjective Optimization of Concrete Frames by Simulated Annealing", ComputAided Civ. Inf., 23, 596-610, 2008.

[22] C. Perea, J. Alcala, V. Yepes, F. Gonzalez-Vidosa, A. Hospitaler, "Design of reinforced concrete bridge frames by heuristic optimization", Adv. Eng. Softw., 39, 676-688, 2008.

[23] I. Paya-Zaforteza, V. Yepes, A. Hospitaler, F. Gonzalez-Vidosa, "CO2optimization of reinforced concrete frames by simulated annealing", Eng. Struct., 31, 1501-1508, 2009.

[24] C.V. Camp, F. Huq, "CO2 and cost optimization of reinforced concrete frames using a big bang-big crunch algorithm", Eng. Struct., 48, 363372, 2013.

[25] O.K. Erol, I. Eksin, "A new optimization method: Big bang big crunch", Advances in Engineering Software, 37, 106-111, 2006.

[26] A. Kaveh, O. Sabzi, "Optimal design of reinforced concrete frames Using big bang-big crunch algorithm", Int. J Civil Eng.,10(3), 189-200, 2012.

[27] B. Ceranic, C. Freyer, R.W. Baines, "An application of simulated annealing to the optimum design reinfroced concrete retaining structure", Comput. Struct., 79, 1569-1581, 2001.

[28] V. Yepes, J. Alcala, C. Perea, F. Gonzalez-Vidosa, "A parametric study of optimum earth-retaining walls by simulated annealing", Eng. Struct., 30, 821-830, 2008

[29] C.V. Camp, A. Akin, "Design of Retaining Walls Using Big Bang-Big Crunch Optimization”, J Struct. Eng.-ASCE, 138(3), 438-448, 2012.

[30] A. Kaveh, A.S.M. Abadi, "Harmony search based algorithms for the optimum cost design of reinforced concrete cantilever retaining walls", Int. J Civil Eng., 9(1), 1-8, 2011.

[31] S. Talatahari, R. Sheikholeslami, M. Shadfaran, M. Pourbaba, "Optimum Design of Gravity Retaining Walls Using Charged System Search Algorithm." Mathematical Problems in Engineering, Vol. 2012, pp. 1-10, 2012.

[32] Temur R, Bekdaş G. Teaching Learning-Based Optimization for Design of Cantilever Retaining Wall. Structural Engineering and Mechanics, 2016; 57(4): 763-783.

[33] Z.W. Geem, J.H. Kim, G.V. Loganathan, "A new heuristic optimization algorithm: harmony search", Simulation, 76, 60-68, 2001.

[34] A. Akin, M.P. Saka, "Optimum Detailed Design of Reinforced Concrete Continuous Beams using the Harmony Search Algorithm", In: B.H.V. Topping, J.M. Adam, F.J. Pallarés, R. Bru, M.L. Romero, (Editors), "Proceedings of the Tenth International Conference on Computational Structures Technology", Civil-Comp Press, Stirlingshire, UK, Paper 131, doi:10.4203/ccp.93.131, 2010.

[35] A. Akin, M.P. Saka, "Optimum Detailing Design of Reinforced Concrete Plane Frames to ACI 318-05 using the Harmony Search Algorithm", in B.H.V. Topping, (Editor), "Proceedings of the Eleventh International Conference on Computational Structures Technology", Civil-Comp Press, Stirlingshire, UK, Paper 72, doi:10.4203/ccp.99.72, 2012.

[36] G. Bekdaş, S.M. Nigdeli, "Cost Optimization of T-shaped Reinforced Concrete Beams under Flexural Effect According to ACI 318." In: 3rd European Conference of Civil Engineering, December 2-4 2012, Paris, France, 2012. 
Proc. of the Fourth International Conference on Advances in Civil, Structural and Environmental Engineering - ACSEE 2016.

Copyright $\odot$ Institute of Research Engineers and Doctors. All rights reserved.

ISBN: 978-1-63248-114-6 doi: 10.15224/ 978-1-63248-114-6-24

[37] G. Bekdas, S.M. Nigdeli, "Optimization of T-shaped RC Flexural Members for Different Compressive Strengths of Concrete", International Journal of Mechanics, 7, 109-119, 2013.

[38] Nigdeli SM, Bekdaş G. Optimum Design of RC Columns According to Effective Length Factor in Buckling. The Twelfth International Conference on Computational Structures Technology, 2-5 September 2014, Naples, Italy.

[39] R. V. Rao, V. J. Savsani, \& D. P. Vakharia, Teaching-learning-based optimization: a novel method for constrained mechanical design optimization problems. Computer-Aided Design, 43(3), 303-315, 2011.

[40] G. Bekdaş, S.M. Nigdeli, Optimum Design Of Reinforced Concrete Columns Employing Teaching Learning Based Optimization. 12th International Congress on Advances in Civil Engineering, 21-23 September 2016, Istanbul, Turkey.

[41] ACI 318M-05, Building code requirements for structural concrete and commentary, American Concrete Institute, 2005.

About Author (s)

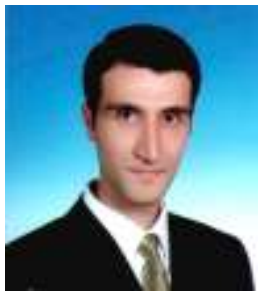

Gebrail Bekdaş, Associative Professor, is researcher in Structural Control and Optimization at Istanbul University. $\mathrm{He}$ obtained his DPhil in Structural Engineering from Istanbul University with a thesis subject of design of cylindrical walls. He co-organized the 15th EU-ME Workshop: Metaheuristic and Engineering in Istanbul. In optimization, he organized several mini-symposiums or special sections in prestigious international events such as the Biennial International Conference on Engineering Vibration (ICoEV-2015), 3rd International Conference on Multiple Criteria Decision Making (MCDM 2015), 11th. World Congress on Computational Mechanics (WCCM2014), International Conference on Engineering and Applied Sciences Optimization (OPTI 2014), 11th Biennial International Conference on Vibration Problems (ICOVP2013), 3rd European Conference of Civil Engineering and $10^{\text {th }}-11^{\text {th }}$ International Conference of Numerical Analysis and Applied Mathematics (ICNAAM). He co-edited Metaheuristics and Optimization in Civil Engineering published by Springer in 2016 and he is one of the guest editors in 2017 special issue of KSCE Journal of Civil Engineering. He has authored more than 100 papers for journals and scientific events.

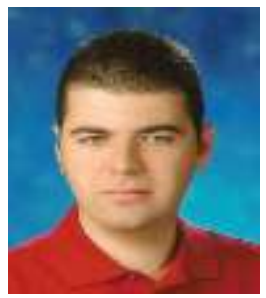

Sinan Melih Nigdeli, Ph.D., is researcher in Structural Control and Optimization at Istanbul University. He obtained his DPhil in Structural Engineering from Istanbul Technical University with a thesis subject of active structural control. He co-organized the 15th EU-ME Workshop: Metaheuristic and Engineering in Istanbul. In optimization and structural control, he organized several minisymposiums or special sections in prestigious international events such as the Biennial International Conference on Engineering Vibration (ICoEV-2015), 3rd International Conference on Multiple Criteria Decision Making (MCDM 2015), 11th. World Congress on Computational Mechanics (WCCM2014), International Conference on Engineering and Applied Sciences Optimization (OPTI 2014), 11th Biennial International Conference on Vibration Problems (ICOVP2013), 3rd European Conference of Civil Engineering and $10^{\text {th }}-$ $11^{\text {th }}$ International Conference of Numerical Analysis and Applied Mathematics (ICNAAM). He co-edited Metaheuristics and Optimization in Civil Engineering published by Springer in 2016 and he is one of the guest editors in 2017 special issue of KSCE Journal of Civil Engineering. He has authored nearly 100 papers for journals and scientific events.

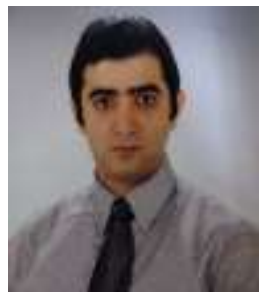

Baris Sayın, Assistant Professor, is currently employed by Department of Civil Engineering at Istanbul University as a Civil Engineer. Dr. Sayin graduated from Istanbul University with $\mathrm{BS}, \mathrm{MS}$ and $\mathrm{PhD}$ in Civil Engineering. During the graduate education, he worked as a Research Assistant in the Department of Civil Engineering at the University in between 2000 and 2009. Dr. Sayin collaborated with Prof. Dr. Hamid Saadatmanesh on CFRP in RC structures as a Visiting Scholar in the Department of Civil Engineering and Engineering Mechanics at The University of Arizona for 12-months from September 2012. His research areas are fiber composites, industrial wastes and RC structures. 